\title{
Physiological traits and yield of three sovbean (Glvcine max (L.) Merr.) genotypes as affected by water deficiency
}

\author{
Oqba Basal - András Szabó \\ University of Debrecen, Faculty of Agricultural and Food Sciences and Environmental Management, \\ Institute of Crop Science, Debrecen \\ oqba@agr.unideb.hu
}

\begin{abstract}
SUMMARY
Soybean is a very important legume; it has the highest protein content, and it is a very important source of vegetable oil. Soybean is droughtsusceptible, and drought is one of the major abiotic stresses that has been increasing over the past decades as a result of the global climatic changes. To evaluate the influence of drought stress, three soybean genotypes were grown under rainfed conditions, and compared to irrigated controls. The obtained results showed that the chlorophyll content, leaf area index and plant height decreased under drought stress conditions, which led to noticeable and sometimes significant yield reduction. Our results suggest more specific studies on the physiological changes of the local soybean genotypes under drought stress to better select the adopted ones.
\end{abstract}

Keywords: Soybean, drought stress, yield, chlorophyll content, leaf area index

\section{INTRODUCTION}

Soybean (Glycine $\max$ (L.) Merr.) is a very important crop for both human consumption and animal feeding because of its high content of protein and oil (Liu et al. 2008). Compared to other legumes, soybean seeds have the highest protein concentration, and are one of the highest in oil concentration, they also contain carbohydrates, minerals and other components (Miransari 2016). Soybean is mostly sown under rainfed conditions, and the current global climatic changes have put this crop under many abiotic stresses with drought stress being the most influencing hazard, because soybean is known to be drought-susceptible crop (Liu et al. 2004, Oh and Komatsu 2015). Drought restrains soybean growth and leads to yield reduction by around 40\% (Manavalan et al. 2009). Moreover, Ishibashia et al. (2011) reported that flowering stage is the most sensitive to drought stress; Ohashi et al. (2006) recorded 20\% yield reduction when soybean was subjected to drought stress during the vegetative stages, whereas the reduction reached about $46 \%$ in the flowering stage; similar results were introduced by Cui et al. (2013). Turner et al. (2005) reported yield reduction by $20 \%$ under drought conditions during seed filling.

Many physiological changes in soybean plants occur as a result of drought stress; these changes lead to growing and development conflictions (Reynolds and Tuberosa 2008). The leaf area index (LAI) is the canopy density of a crop population, and has an important effect on the final yield (Liu et al. 2008). Dong et al. (1979) reported a positive correlation of (LAI) with grain yield of eight cultivars; however, each cultivar had a different leaf size, leaf shape and leaf development (Chang 1981). Shading happens to the lower leaf levels and consequently reduces the (LAI), but still, drought stress decreases the (LAI) more than mutual shading does (Liu et al. 2008).

Chlorophyll content is one of the most important physiological traits, as it reflects the potentials of plant photosynthesis, and consequently, the yield potential. Drought stress influences the chlorophyll content and reduces its value as presented by many researchers; Makbul et al. (2011) recorded significant reduction in chlorophyll content by $28 \%$ in drought-stressed soybean, whereas Hao et al. (2013) found it to be $31 \%$ compared to control plants. Similar results were previously provided by Atti et al. (2004).

Plant height shows the ability of the soybean plants to produce more nodes, and consequently more flowers, pods and seeds. Navari-Izzo et al. (1990) reported a reduction by $4.3 \%$ of soybean seedling height when subjected to drought stress; later, other papers reported similar conclusions at different stages of soybean lifecycle (Atti et al. 2004, Hao et al. 2013, Mak et al. 2014).

It is normal, taking into consideration the abovementioned traits, that the final seed yield will be affected by drought stress; all the previous studies on soybean, under water deficit, reported significant yield loss (e.g. Sadeghipour and Abbasi 2012, Li et al. 2013) regardless of the stage when the drought stress was applied (for example, during pod formation (Sionit and Kramer 1977), or during seed filling (Maleki et al. 2013). The different soybean genotypes were reported to show different yield reductions under drought stress conditions (Bellaloui and Mengistu 2008, He et al. 2016).

The aim of this paper was to study the changes in chlorophyll content, leaf area index, plant height and yield of three different soybean genotypes under certain drought stress conditions.

\section{MATERIALS AND METHODS}

Three soybean genotypes, ES Mentor, ES Gladiator and Pannonia kincse, were sown in Debrecen University's experimental site (Látókép) (N. latitude $47^{\circ} 33^{\prime}$, E. longitude $21^{\circ} 27^{\prime}$ ) on April $26^{\text {th }}$, whereas the harvest was on September $1^{\text {st }}$ for $E S$ Mentor, and on September 15 ${ }^{\text {th }}, 2017$ for both ES 
Gladiator and Pannonia kincse. The soil type is calcareous chernozem; the average annual precipitation is $565.3 \mathrm{~mm}$, whereas the precipitation between sowing and harvesting dates was $213.3 \mathrm{~mm}$ (Figure 1).

Figure 1: Precipitation $(\mathrm{mm})$ and temperature $\left({ }^{\circ} \mathrm{C}\right)$ from the beginning of the year of experiment till the harvesting date
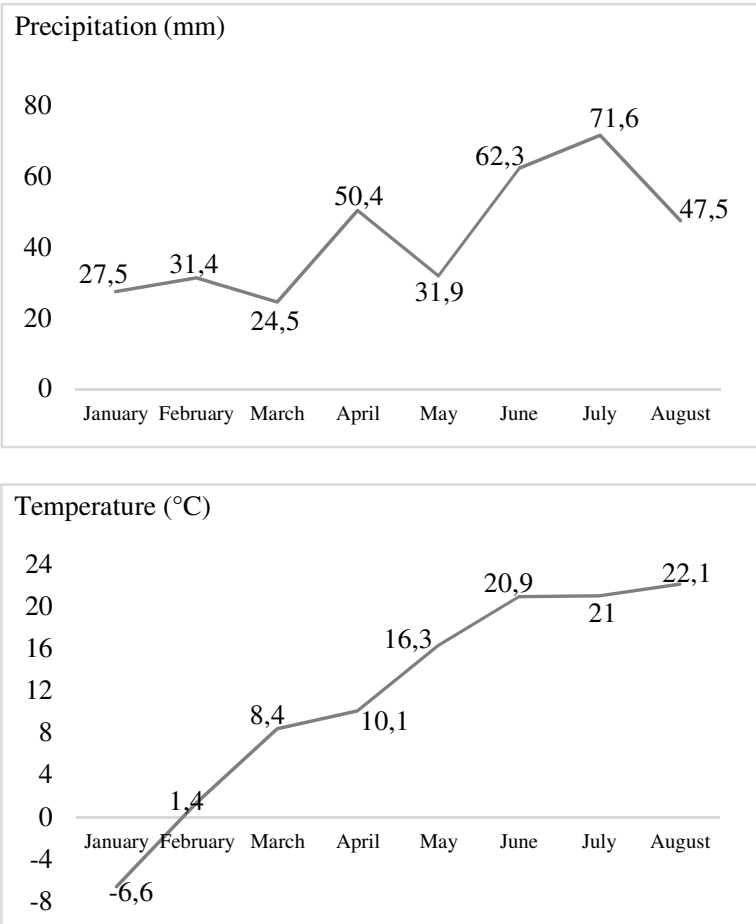

To study the drought stress effects, two treatments were applied with four replications:

- the first treatment was to grow the studied soybean genotypes under irrigation conditions (control plants); the irrigation dates and amounts were as follows:

- June $6^{\text {th }}, 2017: 30 \mathrm{~mm}$,

- June 22 $2^{\text {nd }}, 2017: 25 \mathrm{~mm}$,

- July 22 $2^{\text {nd }}, 2017: 25 \mathrm{~mm}$;

- the other treatment was to grow the three genotypes under rainfed conditions (stressed, no irrigation).

The LAI values were recorded using SS1 SunScan Canopy Analysis System (Delta-T Devices, UK) at three growing stages; vegetative growth V4 (LAI 1), seed filling R5 (LAI 2) and beginning of full maturity R7 (LAI 3). The chlorophyll content was measured using SPAD-502 Plus (Konica Minolta, Japan) in the same previously-mentioned growing stages. Plant height was made manually using a ruler during the maximum flowering stage R2. In every measurement, 10 plants were randomly chosen from each plot.

The statistical analysis was made using SPSS ver.22 software, and Independent Sample T-Test was used to compare the means.

\section{RESULTS AND DISCUSSION}

Leaf Area Index (LAI) was lower for the drought stressed plants of the three genotype, compared to the well-watered plants. Moreover, the difference was significant during the flowering stage for both genotypes ES Mentor and ES Gladiator (Figure 2). Sinclair and Serraj (1995) reported drought stress to cause a reduction in leaf area, and thus reduced protein synthesis and led to yield reduction (Purcell and King 1996). Drought stress reduces the active photosynthetic leaf area and the interception of radiation by the crop canopy, which decreases seed yield (Sinclair et al. 1981, Monteith and Scott 1982). Dong et al. (1979) reported a positive correlation between LAI and grain yield, which was noticed in our experiment, as the non-stressed plants of the three genotypes had higher LAI in all three studied stages, and also higher yields. Jin et al. (2004abcd) concluded that increased LAI during reproductive stages was correlated with increased soybean yield, which was previously reported more specifically as soybean yield was positively related to LAI at R5 (beginning of seed filling) stage (Wells et al. 1982, Kumudi 2002). Regardless of the maturity group, LAI value was the highest during the seed filling stage for both the drought-stressed and the control plants, which is consistent with the findings of Liu et al. (2005) who concluded that genotypes of different maturity groups during the reproductive stages revealed similar LAI tendency; LAI was the highest during seed filling stage (R5) and then it gradually decreased.

For the three studied genotypes, chlorophyll content wasn't affected by drought stress very much during the vegetative and flowering stages; it was even higher sometimes for the drought-stressed plants than for the well-watered ones with no significant differences. This could be understood as the precipitation was fairly high during that stages (Figure 1). However, when plants reached the seed filling stage, the chlorophyll content was considerably lower under drought stress, and the difference was significant for both genotypes ES Mentor and Pannonia Kincse (Figure 2). Earlier, Hossain et al. (2014) found that total chlorophyll content in the leaves of the studied soybean genotypes was lower, under water deficit conditions, than that of wellwatered plants, which is consistent with previous studies (Cui et al. 2004, Pagter et al. 2005). Makbul et al. (2011) recorded a significant decrease in chlorophyll content by $28 \%$ and Hao et al. (2013) by $31 \%$ of drought-stressed soybean compared to control plants. Similar results were provided by Atti et al. (2004). Chang (1981) concluded that high yield could be achieved by an increased LAI.

When well-watered, Chlorophyll content during the seed filling stage for the three genotypes seemed to affect the yield, as the yield was higher when the chlorophyll content was higher (Figure 2). 
Figure 2: SPAD, LAI, Plant height $(\mathrm{cm})$ and yield $\left(\mathrm{kg} \mathrm{ha}^{-1}\right)$ for water deficit and for control plants of the three studied soybean genotypes

\begin{tabular}{|c|c|c|c|c|c|c|c|c|c|c|c|c|c|c|}
\hline \multirow{2}{*}{\multicolumn{2}{|c|}{ ES Mentor }} & \multirow{3}{*}{$\begin{array}{l}\text { Mean } \\
42.84\end{array}$} & \multicolumn{2}{|c|}{$\begin{array}{l}\text { Independent } \\
\text { Samples Test }\end{array}$} & \multirow{2}{*}{\multicolumn{2}{|c|}{ ES Gladiator }} & \multirow{3}{*}{$\begin{array}{l}\text { Mean } \\
41.49\end{array}$} & \multicolumn{2}{|c|}{$\begin{array}{l}\text { Independent } \\
\text { Samples Test }\end{array}$} & \multirow{2}{*}{\multicolumn{2}{|c|}{ Panonia Kincse }} & \multirow{3}{*}{\begin{tabular}{|l} 
Mean \\
43.13
\end{tabular}} & \multicolumn{2}{|c|}{$\begin{array}{l}\text { Independent } \\
\text { Samples Test }\end{array}$} \\
\hline & & & \multirow{3}{*}{$\begin{array}{c}\mathbf{t} \\
.257\end{array}$} & \multirow{3}{*}{\begin{tabular}{|c|}
$\begin{array}{c}\text { Sig. (2- } \\
\text { tailed) }\end{array}$ \\
.806 \\
\end{tabular}} & & & & & \begin{tabular}{|l|} 
Sig. (2- \\
\end{tabular} & & & & & Sig. (2- \\
\hline \multirow{2}{*}{ SPAD 1} & \begin{tabular}{|c|} 
Non \\
Irrigated
\end{tabular} & & & & \multirow{2}{*}{ SPAD 1} & \multirow{2}{*}{\begin{tabular}{|c|}
$\begin{array}{c}\text { Non } \\
\text { Irrigated }\end{array}$ \\
Irrigated \\
\end{tabular}} & & \multirow{2}{*}{1.485} & \multirow{2}{*}{.188} & \multirow{2}{*}{ SPAD 1} & \begin{tabular}{|c|} 
Non \\
Irrigated
\end{tabular} & & \multirow{2}{*}{-1.240} & \multirow{2}{*}{.261} \\
\hline & Irrigated & 42.38 & & & & & 39.80 & & & & Irrigated & 45.77 & & \\
\hline \multirow{2}{*}{ SPAD 2} & \begin{tabular}{|c|} 
Non \\
Irrigated
\end{tabular} & 43.76 & \multirow{2}{*}{-.936} & \multirow{2}{*}{.385} & \multirow{2}{*}{ SPAD 2} & \begin{tabular}{|c|} 
Non \\
Irrigated
\end{tabular} & 38.45 & \multirow{2}{*}{.409} & \multirow{2}{*}{.697} & \multirow{2}{*}{ SPAD 2} & \begin{tabular}{|c|} 
Non \\
Irrigated
\end{tabular} & 38.79 & \multirow{2}{*}{-.533} & \multirow{2}{*}{.613} \\
\hline & Irrigated & 44.49 & & & & Irrigated & 36.64 & & & & Irrigated & 39.77 & & \\
\hline \multirow{2}{*}{ SPAD 3} & $\begin{array}{c}\text { Non } \\
\text { Irrigated }\end{array}$ & 22.40 & \multirow{2}{*}{-4.278} & \multirow{2}{*}{.005} & \multirow{2}{*}{ SPAD 3} & $\begin{array}{c}\text { Non } \\
\text { Irrigated }\end{array}$ & 12.14 & \multirow{2}{*}{-.961} & 271 & ? & $\begin{array}{c}\text { Non } \\
\text { Irrigated }\end{array}$ & 21.84 & 1022 & ?ח? \\
\hline & Irrigated & 28.71 & & & & Irrigated & 16.78 & & & & Irrigated & 33.39 & & \\
\hline 1 & $\begin{array}{c}\text { Non } \\
\text { Irrigated }\end{array}$ & 2.41 & 2237 & 067 & I Al 1 & $\begin{array}{c}\text { Non } \\
\text { Irrigated }\end{array}$ & 1.86 & -1477 & 190 & Il1 & $\begin{array}{c}\text { Non } \\
\text { Irrigated }\end{array}$ & 2.41 & $=009$ & 082 \\
\hline & Irrigated & 2.92 & & & & Irrigated & 2.39 & & & & Irrigated & 3.42 & & \\
\hline 10 & \begin{tabular}{|c|} 
Non \\
Irrigated
\end{tabular} & 5.34 & 7070 & & 1010 & \begin{tabular}{|c|} 
Non \\
Irrigated
\end{tabular} & 5.27 & 5236 & & 19? & \begin{tabular}{|c|} 
Non \\
Irrigated
\end{tabular} & 7.08 & 1012 & 104 \\
\hline & Irrigated & 7.07 & & & & Irrigated & 8.21 & & & & Irrigated & 8.07 & & \\
\hline $141 ?$ & \begin{tabular}{|c|} 
Non \\
Irrigated
\end{tabular} & 0.86 & 575 & 586 & I ? & \begin{tabular}{|c|} 
Non \\
Irrigated
\end{tabular} & 0.97 & 1660 & 118 & 1 & \begin{tabular}{|c|} 
Non \\
Irrigated
\end{tabular} & 2.61 & 1048 & 099 \\
\hline & Irrigated & 1.02 & & & & Irrigated & 1.41 & & & & Irrigated & 3.40 & & \\
\hline $\mathrm{H}$ & $\begin{array}{c}\text { Non } \\
\text { Irrigated }\end{array}$ & 75.25 & 3603 & 040 & . & $\begin{array}{c}\text { Non } \\
\text { Irrigated }\end{array}$ & 87.50 & 673 & 526 & 1 & $\begin{array}{c}\text { Non } \\
\text { Irrigated }\end{array}$ & 76.50 & 3903 & 10 \\
\hline 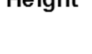 & Irrigated & 82.75 & (1) & .010 & TEmil & Irrigated & 89.50 & (1) & & חетік & Irrigated & 82.25 & -2.000 & .020 \\
\hline & \begin{tabular}{|c|} 
Non \\
Irrigated
\end{tabular} & 3763.50 & 6525 & 001 & Id & $\begin{array}{c}\text { Non } \\
\text { Irrigated }\end{array}$ & 3135.25 & 1273 & 250 & $d$ & $\begin{array}{c}\text { Non } \\
\text { Irrigated }\end{array}$ & 4163.25 & 75 & 3 \\
\hline & Irrigated & 4855.25 & & & & Irrigated & 3533.00 & & & & Irrigated & 4425.50 & & \\
\hline
\end{tabular}

Water stress affected the plant height, as the plants of the three genotypes showed greater value when not subjected to water stress; the difference was insignificant for genotype ES Gladiator (Figure 1), which is consistent with the results of Sionit and Kramer (1977) who reported no significant differences in plant height under drought stress, whereas it was significant for both ES Mentor and Pannonia Kincse genotypes, which is consistent with many previous studies (e.g. Kadhem et al. 1985, Demirtas et al. 2010). Hossain et al. (2014) reported that progressive drought stress significantly decreased plant height of soybean genotypes, but the drought-susceptible genotype response to drought stress was more obvious and plant height was about $44 \%$ of the control plants, whereas the drought tolerant genotypes reached about $58 \%$ (Hossain et al. 2014).

The yield was higher for the well-watered plants compared to the drought stressed ones in the three studied genotypes; moreover, the difference was significant for the genotype ES Monitor, whereas it was not significant for the other two studied genotypes
(Figure 1). All the previous studies reported a yield reduction under drought stress, although different timings of drought stress application were suggested to have different yield loss amounts (e.g. Turner et al. 2005, Demirtas et al. 2010, Maleki et al. 2013).

\section{CONCLUSIONS}

Water deficit has noticeable effects on the soybean physiology and yield. Different soybean genotypes show different reactions against water deficit, but they all tend to have less chlorophyll content, less leaf area index, less plant height under drought stress conditions, which leads to considerable yield losses. Although a one-year experiment is not enough to conclude precise results, it still gives an initial idea on how water deficit may affect the studied soybean genotypes; more demonstrative conclusions can be made after two or three years of experiments. Further studies should also be carried out to detect the most sensitive stage of the current soybean genotypes to drought stress. 


\section{REFERENCES}

Atti, S.-Bonnell, R.-Smith, D.-Prasher, S. (2004): Response of an Indeterminate Soybean [Glycine $\max (\mathrm{L}$.$) Merr.] to Chronic$ Water Deficit During Reproductive Development Under Greenhouse Conditions. Canadian Water Resources Journal. 29. 4: 209-222.

Bellaloui, N.-Mengistu, A. (2008): Seed composition is influenced by irrigation regimes and cultivar differences in soybean. Irrig. Sci. 26: 261-268.

Chang, Y. Z. (1981): LAI of high-yielding cultivation in soybean Sci. Agric. Sin. 2: 22-26.

Cui, W.-Chang, Z.-Li, N. (2013): Effect of drought stress on physiology ecology and yield of soybean. Journal of Water Resources and Water Engineering. 24: 20-24.

Cui, Y. Y.-Pandey, D. M.-Hahn, E. J.-Paek, K. Y. (2004): Effect of drought on physiological aspects of Crassulacean acid metabolism in Doritaenopsis. Plant Sci. 167: 1219-1226.

Demirtas, Ç. D.-Yazgan, S.-Candogan, B. C.-Sincik, M.Büyükcangaz, H.-Göksoy, A. T. (2010): Quality and yield response of soybean (Glycine $\max$ (L.) Merrill) to drought stress in sub-humid environment. African Journal of Biotechnology. 9. 41: 6873-6881.

Dong, Z.-Bin, Y. Q.-Sun, L. Q. (1979): Comparison of cultivar productivity in soybean. J. Shenyang Agric. Coll. 1: 37-47.

Hao, L.-Wang, Y.-Zhang, J.-Xie, Y.-Zhang, M.-Duan, L.-Li, Z. (2013): Coronatine enhances drought tolerance via improving antioxidative capacity to maintaining higher photosynthetic performance in soybean. Plant Science. 210: 1-9.

He, J.-Du, Y. L.-Wang, T.-Turner, N. C.-Yang, R. P.-Jin, Y.-Xi, Y.-Zhang, C.-Cui, T.-Fang, X. W.-Li, F. M. (2016): Conserved water use improves the yield performance of soybean [Glycine max (L.) Merr.] under drought. Agric. Water Manage. http://dx.doi.org/10.1016/j.agwat 2016. 07. 08.

Hossain, Md. M.-Liu, X.-Qi, X.-Lam, H. M.-Zhang, J. (2014) Differences between soybean genotypes in physiological response to sequential soil drying and rewetting. The Crop Journal. 2: 366-380.

Ishibashia, Y.-Yamaguchib, H.-Yuasab, T.-Iwaya-Inoueb, M.Arimaa, S.-Zheng, S. (2011): Hydrogen peroxide spraying alleviates drought stress in soybean plants. Journal of Plant Physiology. 168: 1562-1567.

Jin, J.-Liu, X. B.-Wang, G. H.-Herbert, S. J. (2004a) Physiological comparisons between soybean genotypes differing in maturity and yield. Acta Agronomica Sin. 30: 1225-1231.

Jin, J.-Liu, X. B.-Wang, G. H.-Herbert, S. J. (2004b): Some ecophysiological characteristics at R4-R5 stage in relation to soybean yield differing in maturities. Agric. Sci. China. 3: 425434.

Jin, J.-Liu, X. B.-Wang, G. H.-Li, Y. H. (2004c): The relationship between canopy structure and radiation characteristics during reproductive stages in soybean. J. Northeast Agric. Univ. 35: $412-418$.

Jin, J.-Liu, X. B.-Wang, G. H.-Li, Y. H.-Pan, X. W.-Herbert, S. J. (2004d): Root morphology during the reproductive stages in relation to soybean yield. Soybean Sci. 23: 253-257.

Kadhem, F. A.-Specht, J. E.-Williams, J. H. (1985): Soybean irrigation serially timed during stages R1 to R6. II. Yield component responses. Agron. J. 77: 299-304.
Kumudi, S. (2002): Trials and tribulations: a review of the role of assimilate supply in soybean genetic yield improvement. Field Crops Res. 75. 2-3: 211-222.

Li, D.-Liu, H.-Qiao, Y.-Wang, Y.-Cai, Z.-Dong, B.-Shi, Ch.-Liu, Y.-Li, X.-Liu, M. (2013): Effects of elevated $\mathrm{CO}_{2}$ on the growth, seed yield, and water use efficiency of soybean (Glycine $\max$ (L.) Merr.) under drought stress. Agricultural Water Management. 129: 105-112.

Liu, F. M.-Andersen, N.-Jensen, Ch. R. (2004): Root signal controls pod growth in drought-stressed soybean during the critical, abortion-sensitive phase of pod development. Field Crops Research. 85: 159-166.

Liu, X.-Jin, J.-Herbert, S. J.-Zhang, Q.-Wang, G. (2005): Yield components, dry matter, LAI and LAD of soybeans in Northeast China. Field Crops Research. 93: 85-93.

Liu, X.-Jin, J.-Wang, G.-Herbert, S. J. (2008): Soybean yield physiology and development of high-yielding practices in Northeast China. Field Crops Research. 105: 157-171.

Mak, M.-Babla, M.-Xu, S. C.-O'Carrigan, A.-Liu, X. H.-Gong, Y. M.-Holford, P.-Chen, Z. H. (2014): Leaf mesophyll $\mathrm{K}^{+}, \mathrm{H}^{+}$and $\mathrm{Ca}^{2+}$ fluxes are involved in drought-induced decrease in photosynthesis and stomatal closure in soybean. Environmental and Experimental Botany. 98: 1-12.

Makbul, S.-Saruhan Guler, N.-Durmus, N.-Guven, S. (2011): Changes in anatomical and physiological parameters of soybean under drought stress. Turk. J. Bot. 35: 369-377.

Maleki, A.-Naderi, A.-Naseri, R.-Fathi, A.-Bahamin, S-Maleki, R. (2013): Physiological Performance of Soybean Cultivars under Drought Stress. Bull. Env. Pharmacol. Life Sci. 2. 6: 3844.

Manavalan, L. P.-Guttikonda, S. K.-Tran, L. S. P.-Nguyen, H. T. (2009): Physiological andmolecular approaches to improve drought resistance in soybean. Plant Cell Physiol. 50: 12601276

Miransari, M. (2016): Soybean, Protein, and Oil Production Under Stress. [In: Mohammad Miransari (ed.) Environmental Stresses in Soybean Production.] Soybean Production. Chippenham. Nikki Levy. 2: 157-176.

Monteith, J. L.-Scott, R. K. (1982): Weather and yield variation of crops. [In: Blaxter, K.-Fowden, L. (eds.) Food, Nutrition and Climate.] Applied Science Publishers. Barking. Great Britain. 127-149.

Navari-Izzo, F.-Vangioni, N.-Quartacci, M. F. (1990): Lipids of soybean and sunflower seedlings grown under drought conditions. Phytochemistry. 29. 7: 2119-2123.

Oh, M.-Komatsu, S. (2015): Characterization of proteins in soybean roots under flooding and drought stresses. Journal of Proteomics. 114: 161-181.

Ohashi, Y.-Nakayama, N.-Saneoka, H.-Fujita, K. (2006): Effects of drought stress on photosynthetic gas exchange, chlorophyll fluorescence and stem diameter of soybean plants. Biol. Plant. 50: $138-141$

Pagter, M.-Bragato, C.-Brix, H. (2005): Tolerance and physiological responses of Phragmites australis to water deficit. Aquat. Bot. 81: 285-299.

Purcell, L. C.-King, C. A. (1996): Drought and Nitrogen Source Effects on Nitrogen Nutrition, Seed Growth and Yield in Soybean. J. Plant Nutr. 19: 969-993. 
Reynolds, M.-Tuberosa, R. (2008): Translational research impacting on crop productivity in drought-prone environments. Curr. Opin. Plant Biol. 11: 171-179.

Sadeghipour, O.-Abbasi, S. (2012): Soybean Response to Drought and Seed Inoculation. World Applied Sciences Journal. 17. 1: 55-60.

Sinclair, T.-Serraj, R. (1995): Legume Nitrogen-Fixation and Drought. Nature. 378: 344.

Sinclair, T. R.-Spaeth, S. C.-Vendeland, J. S. (1981): Microclimate limitations to crop yield. [In: Miller, M. H. et al. (eds.) Breaking the Climate/Soil Barriers to Crop Yield.] University of Guelph. Ontario. Canada. 3-27.
Sionit, N.-Kramer, P. J. (1977): Effect of water stress during different stages of growth of soybeans. Agronomy Journal. 69: 274-278.

Turner, N. C.-Davies, S. L.-Plummer, J. A.-Siddique, K. H. M. (2005): Seed Filling in Grain Legumes Under Water Deficits, with Emphasis on Chickpeas. Advances in Agronomy. 87: 211250.

Wells, R.-Schulze, L. L.-Ashley, D. A.-Boerma, H. R.-Brown, R. H. (1982): Cultivar differences in canopy apparent photosynthesis and their relationship to seed yield in soybeans. Crop Sci. 22: 886-890. 